\title{
PÓS-FOTORREPORTAGEM E OS DESAFIOS DAS NOVAS NARRATIVAS AUDIOVISUAIS ${ }^{1}$
}

\section{Posfotorreportaje y los desafíos de las nuevas narrativas audiovisuales}

\section{Post-Photo-Reportage and the Challenges of the New Audiovisual Narratives}

Denis Porto Renó, Universidade Estadual Paulista (Brasil)

denis.reno@unesp.br

Recebido: 30 de setembro de 2019

Aprovado: 31 de janeiro de 2020

Data de pré-publicação: 7 de julho de 2020

\section{RESUMO}

A fotorreportagem é uma modalidade que se ressignificou com a chegada dos ambientes digitais navegáveis, assim como a própria fotografia, redefinida por Fontcuberta (2016) como pós-fotografia. Com base nesta problemática, este artigo oferece resultados qualitativos referentes a uma crescente forma de produção narrativa jornalística, que contempla conteúdos audiovisuais e fotográficos, em uma composição essencialmente imagética, denominada a partir deste trabalho como pós-fotorreportagem. Trata-se de um artigo resultante de investigação aplicada, que tem apresenta a análise da obra Prismas de Marrakech, desenvolvida especificamente para o desenvolvimento desta pesquisa. Como conclusão, apontou-se em direção das definições do conceito de pós-fotorreportagem, que reconfigura a própria produção de reportagens imagéticas jornalísticas. Espera-se, com os resultados aqui apresentados, que o formato possa ser continuamente estudado, dada a sua capacidade cognitiva de oferecer ao usuário uma intensa experiência narrativa com base na imagem. Também espera-se, com a conclusão desta pesquisa, que novos

1 Investigación financiada por Fundo de Amparo a Pesquisa do Estado de São Paulo (FAPESP), ref. proceso 2019/19337-1. 


\title{
DISERTACIONES
}

\section{ENSAYOS}

Estudios sobre imágenes en el nuevo ecosistema mediático

ISSN: $1856-9536$

Doi: https://doi.org/10.12804/revistas.urosario.edu.co/disertaciones/a.8321

Volumen 13, Número 2 / Julio-diciembre 2020

Versión PDF para imprimir desde

http://revistas.urosario.edu.co/index.php/disertaciones

estudos relacionados à fotografia possam ser desenvolvidos, contemplando o crescente espaço ocupado pela reportagem jornalística, cada vez mais presente no cotidiano midiático.

Palavras-chave: comunicação, audiovisual, fotografia, ecologia dos meios.

\section{RESUMEN}

El fotorreportaje es una modalidad que se resignificó con la llegada de los ambientes digitales navegables, así como la propia fotografía, redefinida por Fontcuberta (2016) como postfotografía. Con base en esta problemática, este artículo ofrece resultados cualitativos referentes a una creciente forma de producción narrativa periodística, que contempla contenidos audiovisuales y fotográficos, en una composición esencialmente imaginética, denominada a partir de este trabajo como postfotorreportaje. Se trata de un artículo resultante de investigación aplicada, que presenta el análisis de la obra Prismas de Marrakech, desarrollada específicamente para el desarrollo de esta investigación. Como conclusión, se apuntó en dirección de las definiciones del concepto de postfotorreportaje, que reconfigura la propia producción de reportajes imaginéticos periodísticos. Se espera, con los resultados aquí presentados, que el formato pueda ser continuamente estudiado, dada su capacidad cognitiva de ofrecer al usuario una intensa experiencia narrativa con base en la imagen. También se espera, con la conclusión de esta investigación, que nuevos estudios relacionados a la fotografía puedan ser desarrollados, contemplando el creciente espacio ocupado por el reportaje periodístico, cada vez más presente en la cotidianidad mediática.

Palabras clave: comunicación, audiovisual, fotografía, ecología de los medios.

\begin{abstract}
Photojournalism is a modality that was rethought with the arrival of navigable digital environments, as well as photography itself, redefined by Fontcuberta (2016) as post-photography. Based on this issue, this study offers qualitative results related to a growing form of journalistic narrative production, which includes audiovisual and photographic content, in an essentially imaginary composition, known as post-photojournalism. This study is the result of applied research, which presents the analysis of the work Prismas de Marrakech, created particularly for the development of this research. In conclusion, it highlighted the definitions of the concept of post-photojournalism, which reshapes the very production of imaginary journalistic reporting. With the results presented here, the aim is for the format to be continuously studied, given its cognitive capacity to offer the user an intense narrative experience based on the image. It is also expected that the conclusion from this study will aid in developing new studies related to photography, considering the growing space occupied by journalism, increasingly present in everyday media.
\end{abstract}

Keywords: Communication, audiovisual, photography, média ecology. 


\section{DISERTACIONES}

ENSAYOS

Estudios sobre imágenes en el nuevo ecosistema mediático

ISSN: $1856-9536$

Doi: https://doi.org/10.12804/revistas.urosario.edu.co/disertaciones/a.8321

Volumen 13, Número 2 / Julio-diciembre 2020

Versión PDF para imprimir desde

http://revistas.urosario.edu.co/index.php/disertaciones

Quais os desafios contemporâneos para o desenvolvimento de uma comunicação eficaz? Diversos, certamente. Mas antes de definirmos tais desafios, é fundamental compreender o que é uma comunicação eficaz, atualmente.

Um processo comunicacional, na contemporaneidade, não se limita a construir um processo entre emissor e receptor, como outrora foi valorizado. É importante promover engajamento. É fundamental oferecer experiência de usuário. Ressalta-se, inclusive, esse novo ator midiático -o usuário-, que no passado era identificado como receptor. Esse sujeito já não recebe mensagem. Ele a utiliza, transforma e repercute (ou não). Um processo comunicacional eficaz leva essas características em consideração e as contempla. Do contrário, não comunica de maneira ampla e efetiva.

Com essas definições reconhecidas, podemos pensar nos possíveis desafios a serem encontrados nos processos contemporâneos de comunicação. E, com isso, podemos almejar superá-los. Nesse cenário, o maior desafio é o desenvolvimento de linguagens que contemplem as características de uma comunicação eficaz. Para isso, deve ser considerado como fundamental o desenvolvimento de narrativas complexas, construídas por estruturas fragmentadas, multiplataforma e/ou imagéticas, conectadas através de links a partir de mapas de navegação. Tais mapas, também conhecidos como fluxogramas, possibilitam uma visualização prévia dos possíveis desdobramentos resultantes dos nós neurais presentes na narrativa.

Surge, então, um novo termo nesse cenário: nós neurais. Esse termo resulta da ciência da computação, que passou a considerar estruturas cibernéticas de maneira semelhante às estruturas cerebrais. Trata-se de momentos de decisão em um fluxo de navegação, onde o usuário deve decidir por qual caminho seguir, ou que ação deseja realizar. Esses momentos estão presentes também em estruturas de linguagem e são representados pelos links. Afinal, quando nos deparamos com eles, somos obrigados a decidir se clicamos ou não. Decidimos, então, se expandimos a narrativa ou não. Uma narrativa interativa, hipertextual, é, por si só, expansível. Tais expansões resultam, naturalmente, dos nós neurais.

Outro relevante desafio da comunicação contemporânea é o desenvolvimento de tais narrativas complexas a partir de conteúdos imagéticos, iconográficos, visuais, e não mais textuais, como observamos desde a invenção da prensa por Gutenberg. A sociedade voltou a se comunicar fundamentalmente por imagens. Trata-se de uma comunicação diversa, em uma combinação de vídeo, fotografia, iconografia e mapas que constroem um emaranhado midiático denominado por Fontcuberta (2016) como pós-fotografia. Para o autor, os produtores midiáticos já não diferenciam esses formatos. Muito pelo contrário, reúnem todos eles em um mesmo espaço, potencializando, assim, a comunicação. Isso é justificado por Scolari (2018) como algo necessário para alcançar as potencialidades midiáticas e suas interfaces contemporâneas.

Esse cenário de transformação é facilmente reconhecido pelos estudos sobre ecologia dos meios, termo cunhado por Neil Postman e Marshall McLuhan na década de 1970 e que ganha intensa relevância e visibilidade na contemporaneidade, provavelmente pelos intensos processos de transformação vividos pelos meios. Ao definir o conceito ecologia dos meios, em 1979, os autores sustentam a ideia de que os meios não desaparecem ou são suprimidos por novos. Eles se transformam, resgatando características anteriormente presentes. Dessa forma, 


\section{DISERTACIONES}

ENSAYOS

Estudios sobre imágenes en el nuevo ecosistema mediático

ISSN: $1856-9536$

Doi: https://doi.org/10.12804/revistas.urosario.edu.co/disertaciones/a.8321

Volumen 13, Número 2 / Julio-diciembre 2020

Versión PDF para imprimir desde

http://revistas.urosario.edu.co/index.php/disertaciones

podemos reconhecer a transformação dos meios contemporâneos a partir de seus antecessores, com destaque ao protagonismo da imagem nas narrativas contemporâneas. Meios estes, apoiados nos fundamentais conceitos de rede e mediação.

Este artigo apresenta, a partir de uma investigação aplicada, resultados que sustentam o surgimento da pós-fotorreportagem, um formato jornalístico contemporâneo que adota a imagem como protagonista em suas narrativas. Para tanto, desenvolveu-se a obra Prismas de Marrakech, ${ }^{2}$ com o objetivo de buscar formas de produção de narrativas complexas, sustentadas basicamente, a partir de imagens. Entretanto, através da pesquisa bibliográfica, desenvolveu-se uma revisão referente a dois conceitos fundamentais para sustentar uma narrativa complexa: mediação e redes. Espera-se, com os resultados apresentados neste artigo, contribuir com o desenvolvimento de tais narrativas, tendo como base a imagem.

\section{Pós-fotografia e a ressignificação da imagem}

Quando falamos de pós-fotografia é fundamental considerarmos o significado desse conceito, assim como suas origens. Também é importante considerar a ideia com parcimônia , não aceitando-a sem um olhar crítico, pois o prefixo "pós" sugere que se trata de algo já superado, extinto.

De fato, a fotografia sofreu diversas transformações desde o seu surgimento, a ponto de alguns teóricos ou mesmo fotógrafos considerarem a sua extinção. Entretanto, como propôs McLuhan (1964), não existe extinção de um meio, e sim uma transformação. Não há o fim do jornal impresso, senão a sua transformação em jornal digital. Não há o fim do cinema, senão a sua transformação em plataformas de conteúdo on demand. Dessa forma, não há o fim da fotografia, senão a sua transformação.

Quando Fontcuberta (2016) propõe a existência da pós-fotografia, o faz em alguns momentos de maneira radical, indicando mesmo o fim da fotografia. Porém, em outros momentos, na mesma obra, indica que se trata de uma transformação, mesmo que complexa e intensa. Segundo o autor, "la postfotografía hace referencia a la fotografía que fluye en el espacio híbrido de la sociabilidad digital y que es consecuencia de la superabundancia visual" (p. 93).

Mas a existência do termo não foi cunhado por Fontcuberta, e sim pelo canadense David Tomas, que publicou em 1988 o texto "From the Photograph to Postphotographic practice: Toward a Postoptical Ecology of the eyes". Entretanto, a materialização do conceito resulta dos estudos de Fontcuberta.

Com um olhar otimista, consideramos a pós-fotografia como uma sofisticação da narrativa fotográfica, e não o seu fim, como David Tomas e Joan Fontcuberta apontaram. A partir da pós-fotografia, passamos a conviver com cenários onde a fotografia passou a conviver de maneira harmônica com outros conteúdos imagéticos que dialogam entre si. E mais: constroem potenciais ambientes narrativos que oferecem ao usuário possibilidades de mediação e de navegações por nós neurais.

2 Disponível em https://readymag.com/u14607473/1381280/

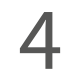




\section{DISERTACIONES}

ENSAYOS

Estudios sobre imágenes en el nuevo ecosistema mediático

ISSN: $1856-9536$

Doi: https://doi.org/10.12804/revistas.urosario.edu.co/disertaciones/a.8321

Volumen 13, Número 2 / Julio-diciembre 2020

Versión PDF para imprimir desde

http://revistas.urosario.edu.co/index.php/disertaciones

\section{Mediação e outras problemáticas}

Mediação é um termo usualmente adotado pela sociedade. No senso comum, mediação significa a relação entre cidadão e meio. Também pode significar qualquer processo mediatizado entre pessoas, entre outros significados, justificando-se tal diversidade de concepções pela elementaridade do termo. Já no contexto científico, esse debate merece mais profundidade, sendo possível de abordar a partir de uma revisão narrativa, como aqui descrito.

Ao pesquisar sobre mediação, encontraram-se diversos textos que abordam a temática, seja no título, no resumo, ou mesmo no conteúdo. $\mathrm{O}$ assunto é naturalmente debatido ou aplicado em estudos sobre meios de comunicação. Pese embora esta diversidade, optou-se por contemplar autores específicos que buscaram definir e defender suas posições sobre mediação. Neste restrito arcabouço científico, destaca-se o espanhol radicado na Colômbia, Jesús Martín-Barbero. Dentre seus diversos estudos, encontra-se como clássico o livro De los medios a las mediaciones - comunicación, cultura y hegemonia, publicado pela primeira vez em 1987. Nesta obra, Martín-Barbero propõe definições e debates que permeiam a construção de conceitos envolvendo a cultura e a hegemonia social a partir da comunicação. Tais ideias concedem uma importância relevante à comunicação para a construção da emancipação social. Mas não o faz a partir dos meios, senão pela mediação, ou seja, dando ao cidadão uma importância até então não concedida nos estudos de meios tradicionais. Ao falar de mediação, Martín-Barbero (1987) propõe rever "los conflictos que articula la cultura, los mestizajes que la tejen y las anacronías que la sostienen, y en últimas del modo en que trabaja la hegemonía y las resistencias que moviliza, del rescate, por tanto, de los modos de apropiación y réplica de las clases subalternas" (p. 240).

Ao ler Martín-Barbero pela primeira vez, os resultados podem seguir no sentido de imaginar uma dissociação do conceito em relação às propostas anteriormente adotadas pela academia, desde as clássicas teorias da comunicação (Hipodérmica e Fluxos de Dois Passos, propostas por Harold Laswell e Paul Lazarsfeld, respectivamente) às mais contemporâneas, propostas por McLuhan (1964) em sua obra Understanding Media, indicando que o meio é a mensagem. Entretanto, segundo o próprio autor, considerar a mediação "no significa la disolución de sus objetos en los de las disciplinas sociales, sino la construcción de las articulaciones - mediaciones e intertextualidades - que hacen su especificidad" (Martin-Barbero, 1987, p. 217).

Outros autores contemporâneos resgatam as ideias de Martín-Barbero, provando que suas ideias pioneiras sobre mediação ainda são vigentes e coerentes com a realidade do ecossistema mediático contemporâneo (sem dúvida com atualizações conceituais, mas dentro de uma mesma filosofia teórica). Segundo Martín-Barbero (1987), mediação é a apropriação, a recodificação e a ressignificação particularmente realizada pelos receptores. Porém, não é viável, aos olhos de Martín-Barbero, dissociar produção, recepção, meio e mensagem, pois estão todos integrados em um processo contínuo. Neste momento, há o intercâmbio entre produção e recepção, especificamente. Finalmente, para o autor, mediação é um processo comunicativo integrador entre cultura e comunicação no cotidiano, de maneira dinâmica. Entre os que resgataram suas ideias na contemporaneidade, destaca-se o argentino Carlos Scolari. Para o autor:

Aun si trabajamos con una definición estrecha del término, podemos sostener con cierta seguridad que existen numerosas formas de comunicación. Hay una comunicación intrapersonal con nosotros mismos, así como hay una comunicación cara a cara (interpersonal), con o sin mediación tecnológica, entre dos 


\section{DISERTACIONES}

ENSAYOS

Estudios sobre imágenes en el nuevo ecosistema mediático

ISSN: $1856-9536$

Doi: https://doi.org/10.12804/revistas.urosario.edu.co/disertaciones/a.8321

Volumen 13, Número 2 / Julio-diciembre 2020

Versión PDF para imprimir desde

http://revistas.urosario.edu.co/index.php/disertaciones

sujetos. Tenemos comunicaciones de grupo y, quizá las más estudiadas a lo largo del Siglo xx, también encontramos las comunicaciones de masas. A principios del Siglo xxı se sospecha la existencia de nuevas formas postmasivas de comunicación (Scolari, 2008, p. 32).

Mas existem outras contribuições sobre mediação, mesmo oriundas das teorias clássicas da comunicação. Considerada como a segunda a ser definida através de uma investigação quantitativa e observacional, a teoria Fluxo de Dois Passos (Two Step Flow), apresentada por Paul Lazarsfeld no início do século passado e citada anteriormente neste texto, acabou gerando diversos outros conceitos, especialmente no campo da mediação. Lazarsfeld, na ocasião, estava preocupado em interpretar os caminhos da comunicação e os atores envolvidos. $O$ investigador posicionava a sociedade como receptor, ainda que antecedido por um novo personagem na tríade emissor-mensagem-receptor: o líder de opinião (Renó, 2007).

Essa forma de interpretar clarificou as ideias de outros autores que, preocupados com a emancipação social e com possíveis mediações, posicionaram os cidadãos como também emissores. Entre eles, destaca-se o jornalista brasileiro Luiz Beltrão que, logo em seus primeiros anos como acadêmico, declarou preocupações que escapavam dos limites dos meios massivos e invadiam os processos. Segundo o próprio autor:

Em 1959, logo que relatei os meus estudos sobre comunicação jornalística, efetuados à base das suas manifestações convencionais, dos seus veículos consagrados - os periódicos, o rádio, a televisão e o cinema - buscando isolar os seus atributos essenciais e apreciar as suas condições filosóficas, senti-me atraído por outros aspectos da difusão de informações e expressão da opinião pública, que escapavam à atividade social a que dedicara os meus esforços de indagação científica (Beltrão, 2001, p. 22).

Em seus estudos, Beltrão observou a existência de outro status comunicacional, que envolvia os cidadãos em todos os processos. O pesquisador criou o conceito batizado por ele mesmo de folkcomunicação, pois observara inicialmente o ciclo mediático dos ex-votos, considerando-os como emissores e mediadores jornalísticos. 0 estudo propunha algumas temáticas inovadoras, especialmente em se tratando do período e do local em que o mesmo foi realizado (meados da década de 1960, no interior do nordeste brasileiro): o cidadão como detentor do poder da mediação e preparado para dispensar as empresas de mídia.

Para tanto, Beltrão criou uma nova tríade de atores midiáticos que posicionava o líder de opinião, proposto por Lazarsfeld, como um líder folkcomunicacional (Renó, 2007) capaz de. reconstruir os conteúdos, as significações e, obviamente, obter novos resultados. Era uma mediação que dava ao cidadão o poder transformador pela informação, seja no jornalismo, na publicidade, na educação ou em qualquer outro processo que envolvesse meios, ressignificando os discursos resultantes dessa remediação. Observou-se uma antecipação científica que constrói um alicerce para a proposta de Martín-Barbero sobre a mediação em um contexto de comunicação e cultura. E conceituou: "folkcomunicação é, assim, o processo de intercâmbio de informações e manifestações de opiniões, ideias e atitudes de massa através de agentes e meios ligados direta ou indiretamente ao folclore” (Beltrão, 2001, p. 39).

A partir das ideias de Beltrão, observou-se que suas ideias sobre mediação compartilhavam conceitos e preocupações com as apresentadas por Martín-Barbero, ainda que possuam nomes diferentes. Enquanto Martín-Barbero denominava o processo como mediação, Beltrão a batizava como algo mais amplo, envolvendo-o na folkcomunicação. Ainda assim, estão diretamente relacionados.

Porém, com as transformações vividas pelo ecossistema mediático contemporâneo, tornou-se necessário rever as ideias de ambos, especialmente as propostas por Martín-Barbero. Para isso, Scolari desenvolveu a obra 


\section{DISERTACIONES}

ENSAYOS

Estudios sobre imágenes en el nuevo ecosistema mediático

ISSN: $1856-9536$

Doi: https://doi.org/10.12804/revistas.urosario.edu.co/disertaciones/a.8321

Volumen 13, Número 2 / Julio-diciembre 2020

Versión PDF para imprimir desde

http://revistas.urosario.edu.co/index.php/disertaciones

Hipermediaciones, que se propõe a recuperar e debater conceitos clássicos diante da nova ecologia dos meios. De entre as teorias debatidas no estudo, a que recebeu maior aporte foi, sem dúvida, a das mediações de Martín-Barbero. Segundo Scolari, essa é a teoria que, provavelmente, tenha sofrido mais alterações, pois envolve não somente processos, mas também comportamentos sociais. E não está limitada somente aos processos tradicionais da comunicação e da informação, e sim com a interconexão humana. Segundo Scolari (2008):

Si la teoría de las mediaciones nos hablaba de los medios masivos y de sus contaminaciones con las culturas populares, las hipermediaciones construyen su mirada científica a partir de los nuevos espacios participativos de comunicación y de su irrupción en lo masivo (pp. 114-115).

O autor destaca que o massivo já não impera nos ambientes mediáticos, e a mediação, que antes já superava os limites "espaciais" dos meios, extrapolando para os processos, passa a conviver com outros cenários. Em suma, para o autor, a mediação se transformou no que ele batiza como hipermediação, considerando os vários caminhos que um processo de mediação pode seguir. Obviamente, essa transformação é potencializada pelo advento de novas possibilidades tecnológicas, mas não se limita a isso.

Cuando hablamos de hipermediaciones no estamos simplemente haciendo referencia a una mayor cantidad de medios y sujetos sino a la trama de reenvíos, hibridaciones y contaminaciones que la tecnología digital, al reducir todas las textualidades a una masa de bits, permite articular dentro del ecosistema mediático. Las hipermediaciones, en otras palabras, nos llevan a indagar en la emergencia de nuevas configuraciones que van más allá -por encima- de los medios tradicionales (Scolari, 2008, p. 114).

Parafraseando o próprio autor, nem sempre deve-se criar novos nomes para as mesmas coisas, e isso é comum no campo de estudos de meio. Porém, o que Scolari propõe é mais que uma alteração de nome. Ele propõe uma reformulação sobre o conceito de mediação. Pode-se observar que a mediação proposta por Martín-Barbero - que propõe caminhos mediados convencionais - já não funciona em ecossistemas midiáticos contemporâneos, pois os caminhos de remediação perdem o controle frente às possibilidades de expansão dos processos comunicacionais em ambientes digitais. A multiplicidade de canais, de circulação de conteúdos e até mesmo o poder mediático dos cidadãos contemporâneos alteram a sua significação. Diante disso, o mais apropriado em alguns anos, será adotar o conceito de hipermediação para compreender os novos cenários de conexão humana.

\section{Prismas de Marrakech como uma pós-fotorreportagem audiovisual}

O desenvolvimento do experimento Prismas de Marrakech se deu a partir da conceituação apresentada neste texto, tendo como alicerce os conceitos de Hipermediação, rede, nós neurais e pós-fotografia. Com esses conceitos solidamente definidos, iniciou-se a construção do fluxograma da pós-fotorreportagem (figura 1). Para tanto, considerou-se uma plataforma com navegação sequencial, ainda que fosse possível saltar por alguma das páginas. Também considerou-se a ideia de experimentar o uso de narrativas imagéticas como protagonistas da história, deixando o conteúdo textual na penúltima página. Após a definição do fluxograma, a fotorreportagem foi montada na plataforma escolhida para o projeto. Optou-se pela plataforma ReadyMag por ser grátis e oferecer uma maior diversidade de recursos. 


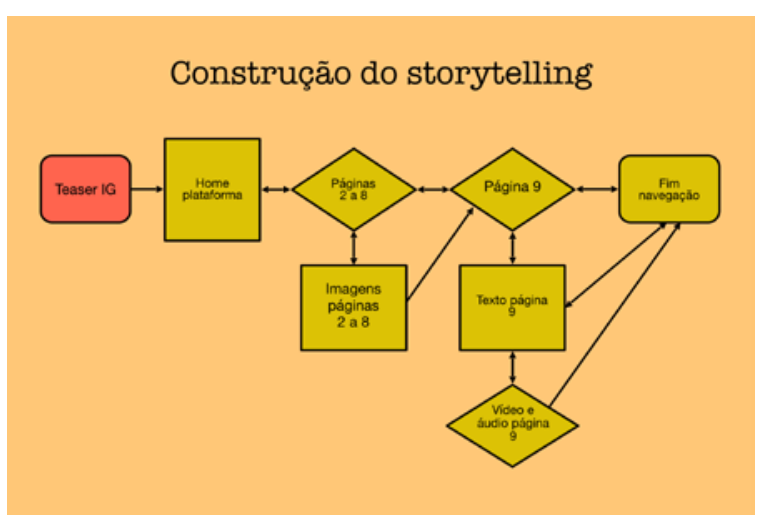

Figura 1. Fluxograma Prismas de Marrakech

A partir do fluxograma, começou-se a construir a plataforma, inicialmente pela capa. Para tanto, escolheu-se uma tipologia como básica para título e subtítulos. O parâmetro para a escolha foi apoiado na necessidade da mesma lembrar os traços da escrita árabe, o que foi obtido com a conclusão da definição. Também decidiu-se que a imagem da capa deveria posicionar o usuário como um observador "presencial", de preferência levando-o para uma sensação de mistério. Com esse parâmetro, optou-se pela fotografia presente na capa da obra, que registra o instante em que um marroquino passa pelo arco de uma passagem da cidade (figura 2). Ainda sobre a primeira página, respeitou-se as regras dos quadrantes para posicionar o título da reportagem na página, deixando-o no primeiro quadrante ocidental (superior esquerdo).

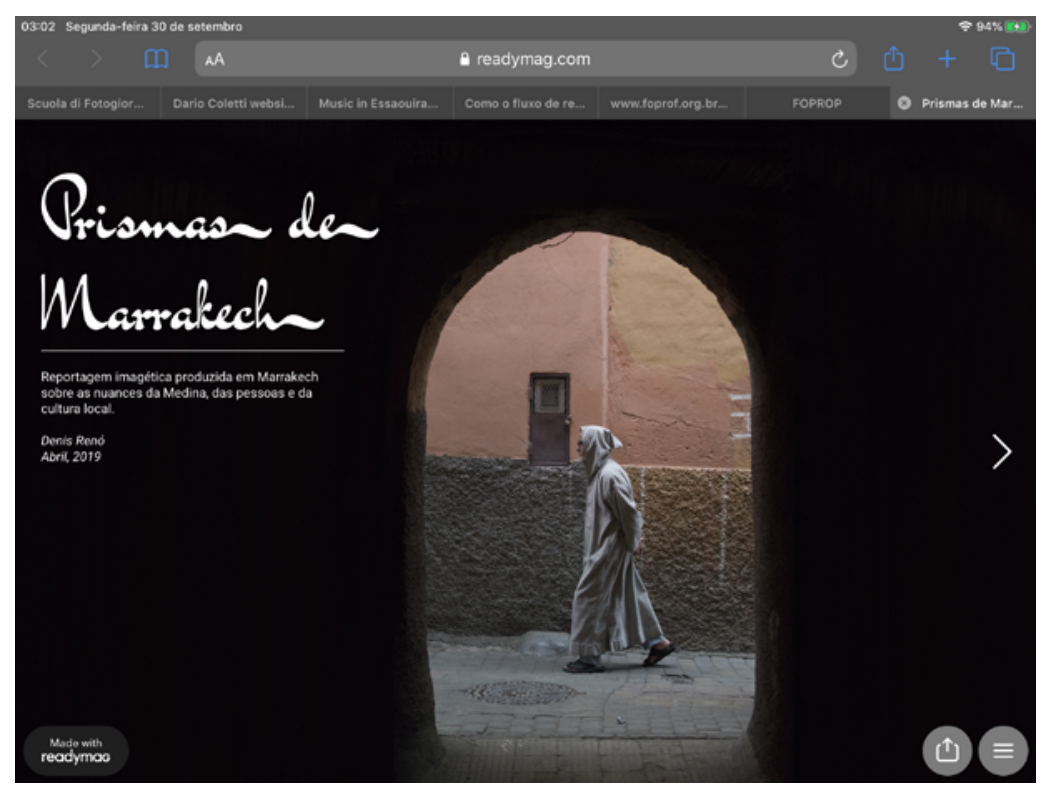

Figura 2. Capa da pós-fotorreportagem Prismas de Marrakech 
A segunda página da obra oferece um mapa interativo da Medina, a cidade murada de Marrakech, é um argumento da pós-fotorreportagem. Observa-se algo interessante nesse formato de produção, que é a semelhança a uma obra audiovisual convencional. O conceito de pós-fotorreportagem advém da pós-fotografia proposta por Fontcuberta (2016), para quem:

La postfotografía hace referencia a la fotografía que fluye en el espacio híbrido de la sociabilidad digital y que es consecuencia de la superabundancia visual. Aquella aldea global veticinada por Marshall McLuhan se inscribe ahora en la iconosfera, que ya no es una mera abstracción alegórica: habitamos la imagen y la imagen nos habita (p. 93).

Com essa definição, o autor já posiciona a pós-fotografia como algo exclusivo do mundo digital contemporâneo, especialmente na superabundância de imagens como narrativa. Nesse espaço, podemos encontrar a fotografia, mas ele é basicamente constituído por iconografias, o que situa os vídeos, os mapas e as infografia como parte do cenário pós-fotográfico.

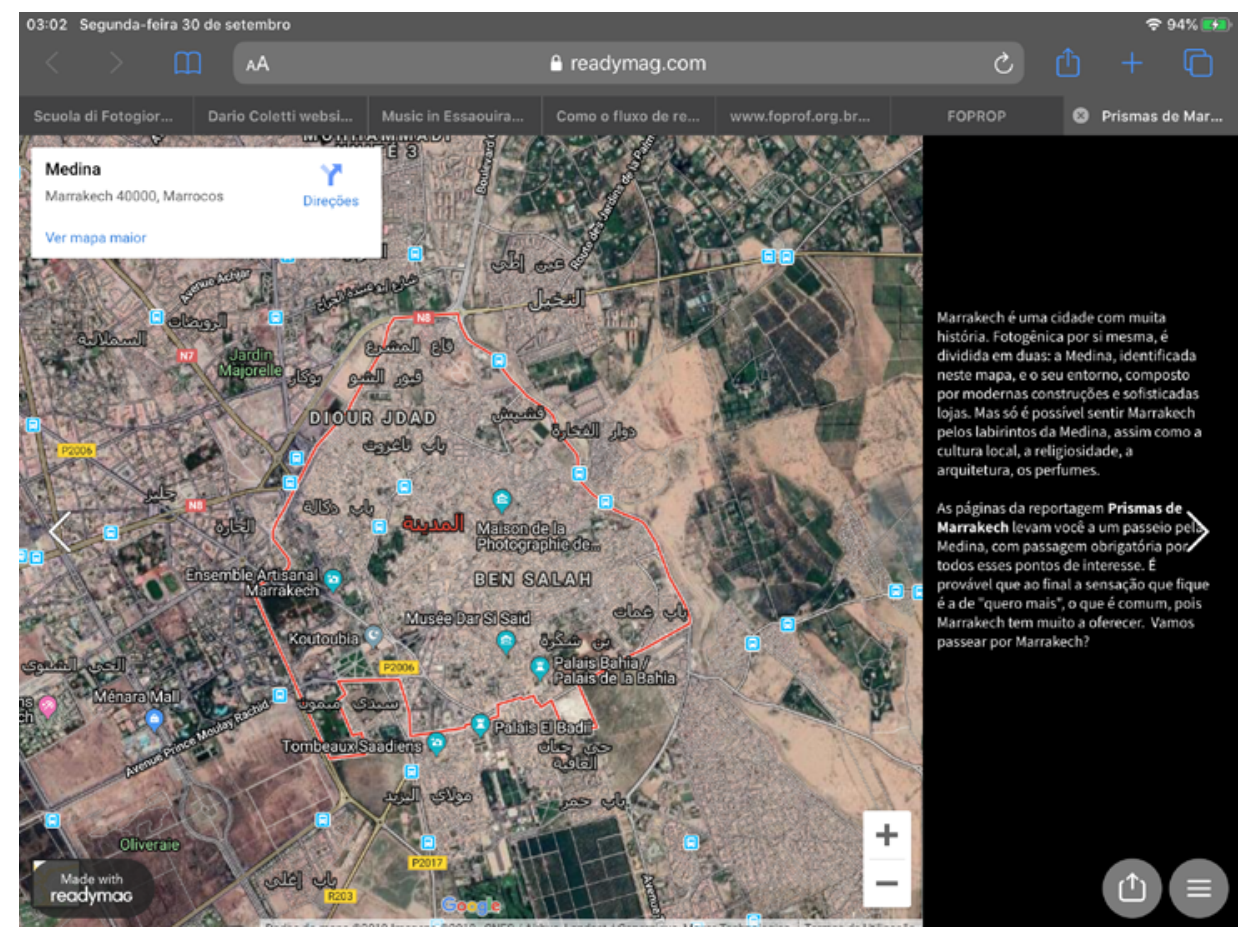

Figura 3. Mapa interativo e argumento da obra

Não há dúvidas que existe uma semelhança dessa obra com as características do audiovisual tradicional, especialmente no que diz respeito ao dialogismo intertextual proposto por Bakhtin (1986). Dialogismo é o que ocorre no cinema constantemente, e graças a isso as narrativas cinematográficas são construídas. Segundo ideias 


\section{DISERTACIONES}

ENSAYOS

de Bakhtin (1986), dialogismo pode ser compreendido como a interação entre diversos textos em um único espaço narrativo. Essa interação passa a ser compreendida como uma reconstrução narrativa que se assemelha à natural, promovida pela sociedade.

A intertextualidade, sustentada pelo dialogismo entre diversas linguagens existentes no audiovisual (imagem, som, luz, silêncio, texto, ritmo de montagem, etc), está visivelmente presente em Prismas de Marrakech, concebida quase que como uma obra audiovisual, com a narrativa passando aos olhos do usuário. A principal diferença está no fato de que o responsável pela exibição e pelo movimento da narrativa é o próprio usuário, em um visível processo de hipermediação. Isso pode ser observado desde a página 3, sobre a arquitetura de Marrakech (figura 4) até a página 8 (figura 5), onde está presente a diversidade cromática das ruas da Medina.

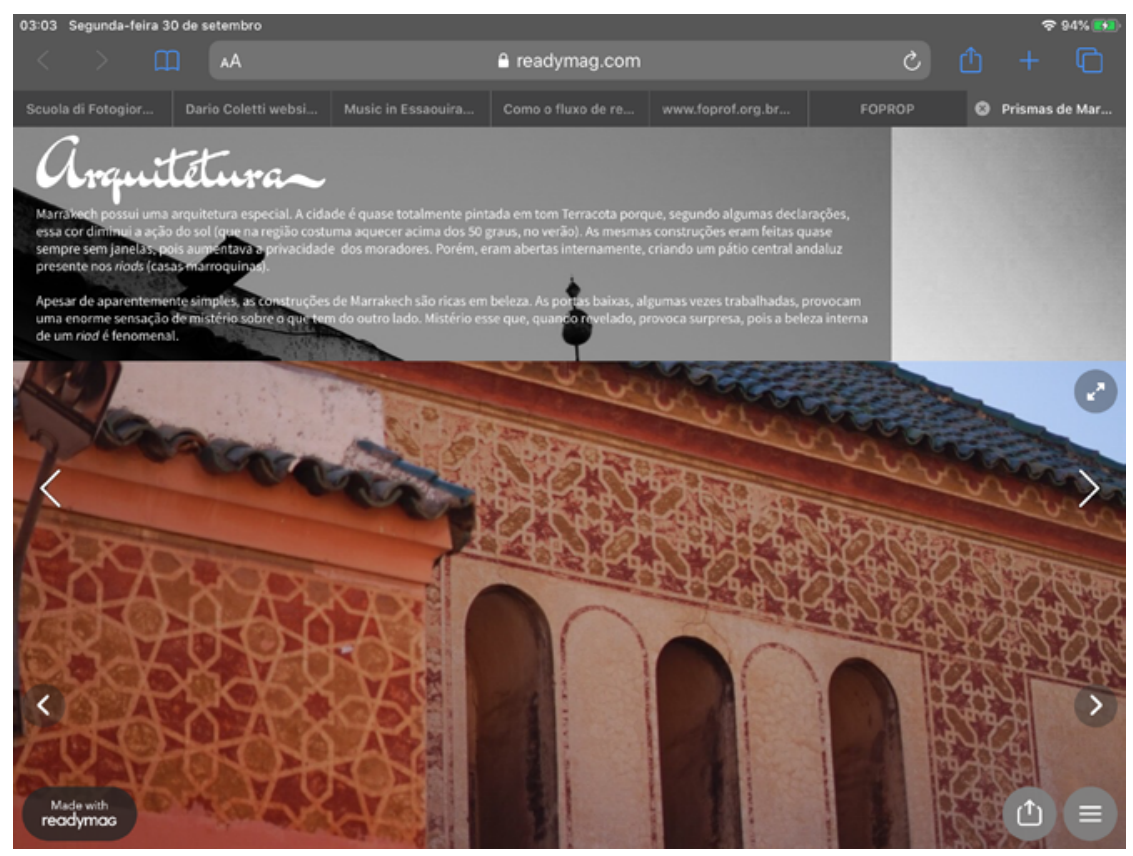

Figura 4. A arquitetura de Marrakech 


\section{DISERTACIONES}

ENSAYOS

Estudios sobre imágenes en el nuevo ecosistema mediático

ISSN: $1856-9536$

Doi: https://doi.org/10.12804/revistas.urosario.edu.co/disertaciones/a.8321

Volumen 13, Número 2 / Julio-diciembre 2020

Versión PDF para imprimir desde

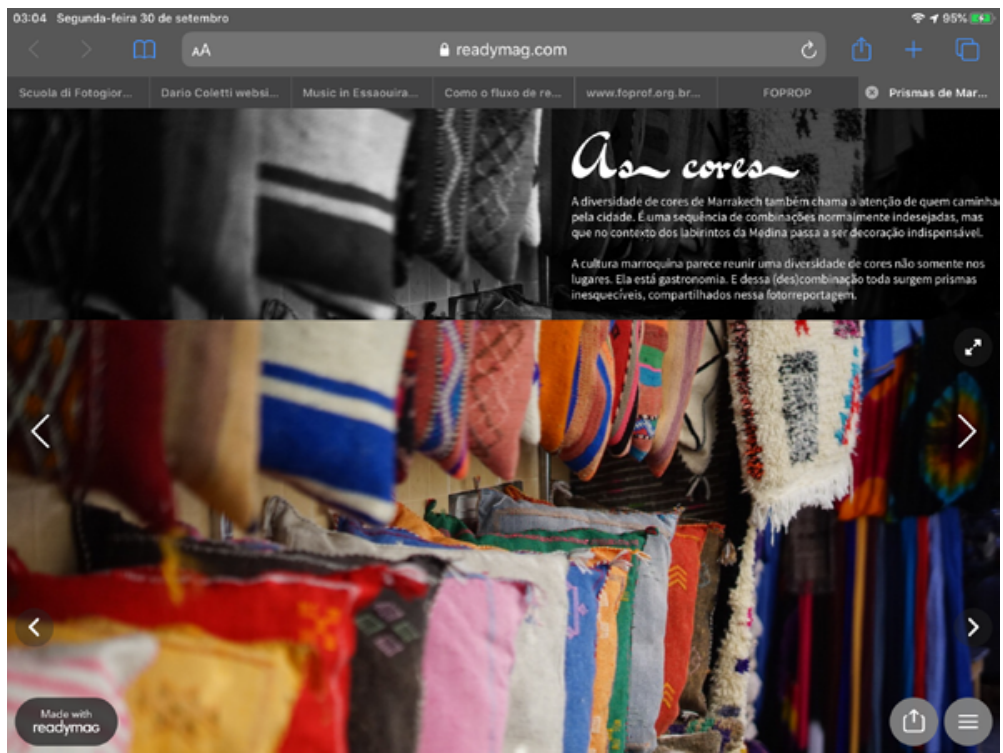

Figura 5. As cores da Medina

A significação de Prismas de Marrakech como uma autêntica obra intertextual está presente na página 9 (figura 6), quando a narrativa lança mão de texto, áudio, vídeo e foto no mesmo espaço para compartilhar experiências e significações cognitivas. Essa diversidade a posiciona efetivamente como uma pós-fotorreportagem, e consolida o formato como algo contemporâneo que atende às expectativas da sociedade digital.
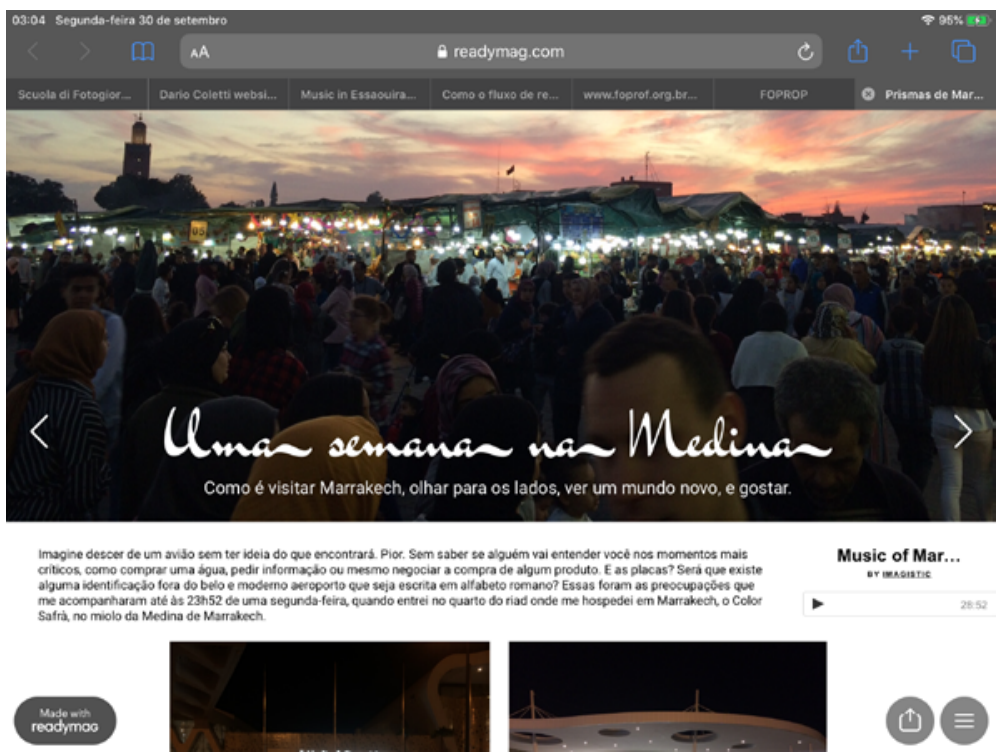

Figura 6. A intertextualidade da obra 


\section{DISERTACIONES}

\section{ENSAYOS}

Essa diversidade é fortalecida por Fontcuberta (2016) ao definir a fúria das imagens na contemporaneidade. Nesse ecossistema de fúria imagética encontramos todos os tipos de narrativas por imagens compartilhando o mesmo espaço. Perdeu-se a fronteira que, segundo Fontcuberta (2016) os fotógrafos pertencentes à old school já não possuem protagonismo. Da mesma forma, seus produtos já não sobrevivem sozinhos em narrativas complexas, especialmente quando o objetivo é, realmente, promover hipermediação, especialmente se esse processo exigir um apoio de redes sociais. Trata-se de um novo mundo, agora binário, que contempla as expectativas sobre pós-fotografia, a partir das ideias de Fontcuberta.

\section{Conclusões}

Diante da investigação apresentada por esse artigo, não nos resta outra alternativa a não ser reconhecer a pós-fotorreportagem como um novo formato do fazer jornalismo, que considera todas as possibilidades imagéticas disponíveis. Trata-se de uma mescla de vídeos, fotos, infográficos, mapas e recursos iconográficos reunidos em um único espaço. O usuário, por sua vez, ao acessar tais conteúdos reunidos em uma narrativa, acabam por iniciar uma experiência audiovisual, com imagens em movimento, mesmo que tal movimentação seja, de fato, simbólica.

Nesse cenário transformador, resta ao jornalista o aprendizado sobre novas narrativas. Vivemos, atualmente, outro momento de reinvenção do jornalismo. Provavelmente este seja o mais expressivo momento de reinvenção do jornalismo desde o seu surgimento. Nele, os jornalistas devem dedicar-se a conhecer esses novos formatos, aqui sustentados pela pós-fotorreportagem, que, por sua vez, oferece vastos potenciais para visualização a partir de dispositivos contemporâneos.

\section{Referências}

1. Bakhtin, M. (1986). Marxismo e filosofia da linguagem (original russo de 1929). São Paulo: Editora Hucitec.

2. Beltrão, L. (2001). Folkcomunicação: um estudo dos agentes e dos meios populares de informação de fatos e expressão de ideias. Porto Alegre: Editora PUCRGS.

3. Fontcuberta, J. (2016). La furia de las imágenes. Madri: Galáxia de Gutenberg.

4. Martin-Barbero, J. (1987). De los medios a las mediaciones - comunicación, cultura y hegemonía. Barcelona: Gustavo Gili.

5. McLuhan, M. (1964). Understanding Media - the extensions of man. Nova lorque: McGrawHill.

6. Renó, D. (2007). YouTube, el mediador de la cultura popular en el ciberespacio. Revista Latina de Comunicación Social, 1(62), 190-196. Recuperado de http://www.revistalatinacs.org/200717Denis_Reno.htm

7. Scolari, C. (2018). Las leyes de la interfaz. Barcelona: Gedisa.

8. Scolari, C. (2008). Hipermediaciones - elementos para una teoría de la comunicación digital interactiva. Barcelona: Gedisa. 